from kidbar until weaning. Kids of both groups $B$ and $C$ were abruptly weaned at 6 weeks of age. The live weight of kids at 10 weeks of age was $12.1,13.1$ and $12.1 \mathrm{~kg}$ on an average in Groups $\mathrm{A}, \mathrm{B}$ and $\mathrm{C}$, respectively. Kid performances were satisfactory in all groups. However, abrupt weaned kids (Group C) exhibited a lower growth rate during the first 2-3 weeks post weaning.

In three trials with 107 kids the effect of feeding acidified skim milk from 5 to 10 weeks of age (group II) was compared to weaning with fermented milk replacer at 6 weeks of age (Group 1). Kids of group I were fed at a similar schedule as kids of group A above. Kids of Group II got 1-2 1 skim milk each per day from 5-10 weeks of age. All kids were weaned like those of Group A. Skim milk was acidified by adding 0.15 p. 100 acetic acid. Live weight at 10 weeks of age was 12.9 and $12.7 \mathrm{~kg}$ on an average in Group I and II, respectively. The skim milk fed kids suffered from diarrhoea. Thus feeding skim milk showed no beneficial effect on kid performance. Well growing kids can casily be weaned on dry feed at 6 weeks of age without any reduction in growth rate.

Key words : Teat feeding, kid, weaning, milk replacer, fermented milk.

\title{
The use of starch and soybean protein in intensive rearing of veal-type kids
}

\author{
Zafrira NITSAN, Y. CARASSO, I. NIR \\ Agricultural Research Organisation, The Volcani Center, Ministry of Agriculture, \\ The Hebrew University of Jerusalem, Faculty of Agriculture, Rehovot, Israel
}

The cost of milk replacers fed to suckling calves, lambs or kids, can be reduced by substituting part of the milk ingredients by feeds of plant origin. The present work was intended to determine the maximal amount of starch-soy mixture which is efficiently utilized by suckling kids when given in a liquid form. The effect of starch-soy mixture on the development of the gastrointestinal tract (GIT), the weight gain and the carcass fattening of kids was studied and compared to kids fed milk replacer or dry concentrate.

Twenty four Saanen male kids, about one week old, with an average weight of $4.6 \mathrm{~kg}$ were divided into 4 equal groups and kept in individual cages. The different groups received : 1) milk replacer $(M)$; 2) milk replacer + increasing amounts of heat treated corn starch-soy mixture (2:1) up to 30 p. 100 (TS) ; 3) as group 2 , but with raw corn starch up to 60 p. $100(\mathrm{~S}) ; 4)$ weaned at $38 \mathrm{~d}$ with free access to dry concentrate (C). The soystarch mixtures were combined with the milk replacer and fed together. In group 2 starchsoy mix was not increased above 30 p. 100 because at higher level food intake was depressed due to an excessive viscosity of the liquid replacer.

Kids were slaughtered when their weight attained or exceeded $18 \mathrm{~kg}$. The segments of the GIT were removed and weighed with and without their contents. The contents was stored at $-20^{\circ} \mathrm{C}$ for further analysis.

Feeding dry concentrate increased the weight of the 4 stomachs by $45 \mathrm{~kg} / \mathrm{kg}$ body weight in the dry concentrate fed kids vs about 18 in liquid dict fed ones. The weight of the intestine was not affected. Among the groups fed lipid diets, addition of starch-soy mixture sightly increased the weight of the rumen, reticulum and omasum and decreased the weight of the abomasum. The caecum of the $\mathrm{S}$ kids was significantly larger than in the other groups.

The pancreas weight was larger in the $S$ and $C$ kids than in $M$ and TS ones. The thickness of the small and large intestine estimated by the weight $(\mathrm{g}) / \mathrm{length}(\mathrm{m})$ ratio was largest in the $M$ group. 
In the TS and $C$ groups the starch content in the small intestine, caecum and large intestine varied between 0.5 and $1.5 \mathrm{~g}$; in the $\mathrm{S}$ group it varied between 10 and $19 \mathrm{~g}$. The high intestinal starch content in the $\mathrm{S}$ group was accompanied by a reduced $\mathrm{pH}$ mainly in the caecum and in the large intestine.

Although the intestine of $S$ kids contained more starch than that of TS ones, heattreated starch stimulated higher apparent amylase secretion than raw starch. Trypsin activity was higher in the pancreas and small intestine of the $S$ and $C$ groups than in their $M$ and TS counterparts. This could be due to the higher consumption of soybean protein.

The adaptive capacity of the intestine to digest and absorb starch is limited in kids, therefore, the amount of starch that can be included in a liquid dict should be quantified accordingly.

The daily body gain was $232,226,202$ and $175 \mathrm{~g}$ in groups $\mathrm{M}, \mathrm{TS}, \mathrm{S}$ and $\mathrm{C}$, respectively. The final body weight which was attained after $65,65,73$ and $76 \mathrm{~d}$ was 19.6, 19.3, 19.5 and $18.2 \mathrm{~kg}$ for the respective groups.

The utilization of dry matter, protein and energy was significantly lower in S and $\mathrm{C}$ groups than in $\mathrm{M}$ and TS ones. Feed/Gain ratios were $1.35,1.40,1.72$ and 2.09 in $\mathrm{M}$, TS, $\mathrm{S}$ and $\mathrm{C}$ groups, respectively.

Body fat - around kidneys and along the gastrointestinal tract (GIT) - was related to the amount of milk replacer consumed, so was the carcass grade. The weight of the kidneys and GIT fat was $986,759,620$ and $298 \mathrm{~g}$ for M, TS, S and C groups, respectively. The carcass grade (according to veal calves, when $1=$ white and $4=$ red) was $1,2,3,3.2$ in the respective groups.

When maximal growth is required in order to reach market weight in the shortest period, feeding liquid diets is recommended, the substitution of part of the milk replacer by starch-soy mixture may be economical.

Key words : Milk replacer, soybean, starch, kid, gastrointestinal tract.

\title{
Effects of nutritional factors, castration and weight at slaughter on fattening of male kids
}

\author{
P. MORAND-FEHR, P. BAS, J. HERVIEU
}

Station de Nutrition et Alimentation (I.N.R.A.) de II.N.A. P.G. 16, rue Claute-Bernard, 75231 Paris Cedex 05

Kid carcasses have a lower fat content than those of other ruminants (Morand-FeHR et al., 1976), but their commercial value is improved by increasing their fattening score (MORAND-FEHR et al., 1980). In two experiments, we tried to improve the fattening of kid carcasses by increasing live weight at slaughter or fat content of milk substitute, by using goat milk or by castration.

In experiment I, two types of milk containing 18 and 23 p. 100 fat were given to 36 male Alpine kids slaughtered at $8-9,14-15$ and $20-21 \mathrm{~kg}$ live weight. Increase in live weight at slaughter improved the fattening scores of carcasses $(3.83,4.12,4.45)$ respectively and the weight of adipose tissues (Omentum : $67.5 \mathrm{~g}, 253.1 \mathrm{~g}, 459.3 \mathrm{~g}$; Perirenal fat : $89.8 \mathrm{~g}, 189.0 \mathrm{~g}, 288.1 \mathrm{~g}$ respectively). The high fat milk substitute did not significantly increase the fattening score of carcasses. The weight of omental adipose tissue was significantly higher with the high fat milk substitute at $14 \mathrm{~kg}(268.8 \mathrm{~g}$ vs $237.3 \mathrm{~g})$ and $20 \mathrm{~kg}$ live weight $(487.2 \mathrm{~g}$ vs $431.3 \mathrm{~g})$. The perirenal tissue showed the same trend but not significantly.

In experiment II, goat milk or a milk substitute containing 22 p. 100 fat were given to 24 kids which were slaughtered at $14-16 \mathrm{~kg}$ live weight. Two other groups, one composed of entire male kids and the other of castrated kids were given the same milk substitute and slaughtered at $20-22 \mathrm{~kg}$ live weight. The fattening score was improved with goat milk 